\title{
Alteration in cellular fatty acid composition as a response to salt, acid, oxidative and thermal stresses in Lactobacillus helveticus
}

\author{
M. Elisabetta Guerzoni, ${ }^{1}$ Rosalba Lanciotti ${ }^{1}$ and P. Sandro Cocconcelli ${ }^{2}$
}

Author for correspondence: M. Elisabetta Guerzoni. Tel:+3905120997 83. Fax: +390512099782. e-mail: guerzoni@foodsci.unibo.it

1 Dipartimento di Protezione e Valorizzazione Agroalimentare, University of Bologna, via S. Giacomo 7, 40126 Bologna, Italy

2 Istituto di Microbiologia, Centro Ricerche Biotecnologiche, University Cattolica del Sacro Cuore Piacenza-Cremona, via Emilia Parmense 84, 29100 Piacenza, Italy
The fundamental question in this study is concerned with whether the increase of unsaturated fatty acids in the cell membrane is a general response of certain thermotolerant strains or species when exposed to superoptimal temperatures, and in combination with other stresses, especially oxidative stress. A strain of Lactobacillus helveticus, a species widely used as a starter in the dairy industry and able to tolerate high temperature and $\mathrm{NaCl}$ concentrations as well as acidic conditions, was chosen for this study. Cells of strain CNBL 1156, grown in its natural medium (i.e. milk whey), were exposed for $100 \mathrm{~min}$ to sublethal combinations of temperature, $\mathrm{NaCl}, \mathrm{H}_{2} \mathrm{O}_{2}$ and $\mathrm{pH}$, modulated according to a Central Composite Design. The fatty acid composition of cell lipid extract was identified by GC/MS. Polynomial equations, able to describe the individual interactive and quadratic effects of the independent variables on cell fatty acid composition, were obtained. The results and the mathematical models relative to the individual fatty acids indirectly suggest that desaturase activation or hyperinduction play an important role in the response to heat stress. In fact, the relative proportions of oleic, linoleic and palmitic acids increased with temperature in a range between 38 and $54{ }^{\circ} \mathrm{C}$. The fatty acid profiles included vernolic acid (up to $37 \%$ of total fatty acids), an epoxide of linoleic acid not previously reported in microbial cells. In particular, this epoxide was present in cells exposed to low pH in combination with high temperatures and oxidative stress. In conclusion, these results provide experimental support to the hypothesis that the increase of an oxygen-consuming desaturase system, with a consequent increase in fatty acid desaturation, is a cellular response to environmental stresses able to protect the cells of this anaerobic micro-organism from toxic oxygen species and high temperatures.

Keywords: sublethal stresses, oxidative stress, thermal stress

\section{INTRODUCTION}

The biological function of lipids in microbial cells is manifold and, consequently, a large body of research is devoted to lipids and their role in cell physiology (Cronan \& Gelmann, 1975; Fulko, 1983; Rattray, 1988; Ratledge \& Wilkinson, 1989; Russell \& Fukanaga, 1990). The changes in lipid composition enable the micro-organisms to maintain membrane

Abbreviations: CCD, Central Composite Design; CFA, cyclopropane fatty acids; LAB, lactic acid bacteria; ROS, reactive oxygen species; SFA, saturated fatty acid; UFA, unsaturated fatty acid. functions in the face of environmental fluctuations. In particular, the temperature-induced variations in lipid composition of micro-organisms are generally thought to be associated with the regulation of liquid-crystallineto gel-phase transition temperature for the maintenance of an ideal 'functional' physiological state of cell membrane. It is generally reported that the proportion of lower melting point lipids increases with a decrease in growth temperature. Appropriate proportions can be reached by increasing the degree of fatty acid unsaturation, branching or decreasing the fatty acid chain length, although a great diversity of responses has been observed (Suutari \& Laakso, 1994). 
Similarities exist in the temperature regulation of fatty acid biosynthesis within the various groups of microorganisms. The increase of unsaturation, on reducing the growth temperature, has been described for several microbes (Russell \& Fukanaga, 1990; Suutari et al., 1990) and can be regarded as a universally conserved adaptation response (Suutari \& Laakso, 1994). However, the regulation of the biosynthetic routes of fatty acids in the majority of micro-organisms has been poorly studied. In particular, the way in which the fatty acid composition of membrane lipids is altered in response to growth temperature appears to depend on the mechanism of unsaturated fatty acid (UFA) synthesis utilized (Keweloh \& Heipieper, 1996). In bacteria, both anaerobic and aerobic mechanisms are responsible for the synthesis of UFA (Aguilar et al., 1998). In certain bacteria and eukaryotes the introduction of double bonds into saturated fatty acids (SFA) is catalysed by oxygen-dependent desaturation of the full-length fatty acid chain, on either an acylthioester or a phospholipid fatty acid moiety, and requires a specific electron transport chain. In bacilli desaturase synthesis transcription initiation is associated only with the transfer from high to low temperatures (Okuley et al., 1994) and, similar to other microbes as well as eukaryotes, the desaturation system is reported as a cold-inducible process. However, in apparent disagreement with this mechanism, it has been shown that thermotolerance in Saccharomyces cerevisiae is associated with a response mechanism involving an increased degree of fatty acid unsaturation when the cells were exposed to superoptimal temperatures, particularly in combination with oxidative stress (Guerzoni et al., 1997). Moreover, in thermotolerant strains of $S$. cerevisiae, as a result of possessing this response mechanism, when temperature approaches the maximal growth temperature, no increase in thiobarbituric-acid-reactive substances (TBARS) was observed in contrast with a remarkable increase of TBARS in the non-thermotolerant strains (Guerzoni et al., 1997). An increase in the proportion of oleic (cis-9-octadecenoic acid) and linoleic (cis-9,cis-12octadecadienoic acid) acids with temperature has also been observed in the thermotolerant Hansenula polymorpha (Wijeyaratne et al., 1986). In this yeast species the relative percentage of UFA proved to be higher at $50{ }^{\circ} \mathrm{C}$ than at $20^{\circ} \mathrm{C}$. Guillot et al. (2000) reported that in Lactococcus lactis at high temperature the UFA/SFA ratio increases from 1.7 to 2.7 . An oxygen-dependent desaturase induction was postulated in thermotolerant yeast strains with the roles of preventing increased oxygen and reactive oxygen species (ROS) accumulation in the membrane at superoptimal temperatures and protecting the cells from damage generated by oxidative and thermal stresses (Guerzoni et al., 1997).

Oxidative stress has been reported to be the result of an imbalance that occurs when the survival mechanisms are unable to deal adequately with the ROS in the cells (Dodd et al., 1997). A partial overlap between oxidative and heat damage responses has been described in microorganisms and a correlation between some oxidant- induced proteins and heat-shock proteins has been observed (Piper, 1995). In fact, the primary consequence of hyperthermia is an enhanced formation of oxygen radicals and their reaction with target molecules. Therefore, it has been reported that certain antioxidant activities are increased by heat stress to counteract ROS formation (Piper, 1995; Schnell et al., 1992; MoradasFerreira et al., 1996). However, although much attention has been devoted to biomolecular aspects concerning the functional overlap of such responses, the thermodynamic aspects regarding $\mathrm{O}_{2}$ availability have been poorly considered. When the cell membranes and culture medium are regarded respectively as lipidic and aqueous phases, the partition of $\mathrm{O}_{2}$ and its molecular species in the membranes is reported to increase with temperature (Perry, 1964; Steels et al., 1994). Guerzoni et al. (1997) proposed an additional response capable of counteracting this increased $\mathrm{O}_{2}$ partition in the membrane and preventing ROS formation at superoptimal temperatures. This mechanism, which was indirectly demonstrated in S. cerevisiae by Guerzoni et al. (1997) was based on the activation of an oxygen-consuming membrane-associated fatty acid desaturase.

In this study we have investigated the increase of UFAs in the cell membrane as a general response of certain thermotolerant strains or species when exposed to superoptimal temperatures, as well as in combination with other stresses, in particular oxidative stress. In this paper we report on the stress response of Lactobacillus helveticus to evaluate whether the desaturase hyperinduction mechanism described above (indirectly evaluated on the basis of fatty acid changes) is shared by other thermotolerant species which do not include sterols in their membrane, are not endowed with catalase and superoxide dismutase and, moreover, do not prevalently use an aerobic pathway for fatty acid synthesis. Lactobacillus helveticus is a thermophilic species of lactic acid bacteria (LAB), widely used as a starter in the manufacturing of Italian and Swiss cheese and for the biotechnological production of lactic acid. During these industrial processes Lactobacillus helveticus cells are exposed to combinations of stress factors, including high temperatures, acidic conditions and the presence of $\mathrm{NaCl}$ and oxygen. In this work the cell fatty acid composition of a strain able to growth up to $53^{\circ} \mathrm{C}$ at least under anaerobic conditions was analysed. In addition, to evaluate the individual and interactive effects of environmental factors on cell fatty acid composition, such as temperature, $\mathrm{NaCl}$ and $\mathrm{H}_{2} \mathrm{O}_{2}$ concentrations, a Central Composite Design (CCD) was developed using whey as culture medium.

\section{METHODS}

Bacterial strain and culture conditions. Lactobacillus helveticus CNBL 11156 was routinely cultivated at $45^{\circ} \mathrm{C}$ in MRS medium (Merck) under anaerobic conditions. The strain used in this study was isolated from natural whey cultures for cheese production and was verified in this environment as the dominant bacterial population when the growth conditions were most stringent: at the beginning of the fermentation 
Table 1. Levels of temperature, $\mathrm{H}_{2} \mathrm{O}_{2}, \mathrm{NaCl}$ and $\mathrm{pH}$ in the 26 runs of the four-factor, five-level CCD

\begin{tabular}{|c|c|c|c|c|}
\hline Run & Temperature $\left({ }^{\circ} \mathrm{C}\right)$ & $\mathrm{H}_{2} \mathrm{O}_{2}(\%)$ & $\mathrm{NaCl}(\mathrm{M})$ & $\mathrm{pH}$ \\
\hline 1 & 50 & 0.005 & $0 \cdot 3$ & $3 \cdot 8$ \\
\hline 2 & 42 & $0 \cdot 013$ & $0 \cdot 3$ & $3 \cdot 8$ \\
\hline 3 & 42 & $0 \cdot 005$ & $0 \cdot 7$ & $3 \cdot 8$ \\
\hline 4 & 50 & $0 \cdot 013$ & $0 \cdot 7$ & $3 \cdot 8$ \\
\hline 5 & 42 & 0.005 & $0 \cdot 3$ & $5 \cdot 0$ \\
\hline 6 & 50 & $0 \cdot 013$ & $0 \cdot 3$ & $5 \cdot 0$ \\
\hline 7 & 42 & $0 \cdot 013$ & $0 \cdot 7$ & $5 \cdot 0$ \\
\hline 8 & 46 & $0 \cdot 009$ & $0 \cdot 5$ & $4 \cdot 4$ \\
\hline 9 & 50 & $0 \cdot 013$ & $0 \cdot 3$ & $3 \cdot 8$ \\
\hline 10 & 50 & 0.005 & $0 \cdot 7$ & $3 \cdot 8$ \\
\hline 11 & 50 & 0.005 & $0 \cdot 3$ & $5 \cdot 0$ \\
\hline 12 & 50 & $0 \cdot 013$ & $0 \cdot 7$ & $5 \cdot 0$ \\
\hline 13 & 42 & $0 \cdot 005$ & $0 \cdot 3$ & $3 \cdot 8$ \\
\hline 14 & 42 & $0 \cdot 013$ & $0 \cdot 7$ & $3 \cdot 8$ \\
\hline 15 & 42 & $0 \cdot 013$ & $0 \cdot 3$ & $5 \cdot 0$ \\
\hline 16 & 42 & 0.005 & $0 \cdot 7$ & $5 \cdot 0$ \\
\hline 17 & 46 & 0.009 & $0 \cdot 5$ & $4 \cdot 4$ \\
\hline 18 & 38 & 0.009 & $0 \cdot 5$ & $4 \cdot 4$ \\
\hline 19 & 54 & 0.009 & $0 \cdot 5$ & $4 \cdot 4$ \\
\hline 20 & 46 & $0 \cdot 001$ & $0 \cdot 5$ & $4 \cdot 4$ \\
\hline 21 & 46 & $0 \cdot 017$ & $0 \cdot 5$ & $4 \cdot 4$ \\
\hline 22 & 46 & 0.009 & $0 \cdot 1$ & $4 \cdot 4$ \\
\hline 23 & 46 & 0.009 & $0 \cdot 9$ & $4 \cdot 4$ \\
\hline 24 & 46 & 0.009 & $0 \cdot 5$ & $3 \cdot 2$ \\
\hline 25 & 46 & 0.009 & $0 \cdot 5$ & $5 \cdot 6$ \\
\hline 26 & 46 & 0.009 & 0.5 & $4 \cdot 4$ \\
\hline
\end{tabular}

process when the temperature was $53^{\circ} \mathrm{C}$ and at the end of the cycle, with a final pH of 3.3 (Cocconcelli et al., 1997).

Stress response experiments were performed by cultivating CNBL 1156 in filter-sterilized whey. Filter-sterilized whey was prepared as follows. Fresh whey, obtained from cheese production, was centrifuged at $8000 \mathrm{~g}$ for $30 \mathrm{~min}$ at $4{ }^{\circ} \mathrm{C}$, filtered onto a Whatman (Polycap $75 \mathrm{SPF}$ ) apparatus, sterilized by filtration on $0.45 \mu \mathrm{m}$ membrane filters (Nalgene) and stored at $4{ }^{\circ} \mathrm{C}$ before use. To test sterility, a sample of the sterilized whey was incubated at $37^{\circ} \mathrm{C}$ for $48 \mathrm{~h}$.

Anaerobic and aerobic growth were achieved by using identical growth media and temperatures $\left(37\right.$ and $\left.42^{\circ} \mathrm{C}\right)$, with provision of permanent aeration for aerobic growth by vigorous shaking by using an orbital shaker at 300 r.p.m., and the use of an anaerobic glove box (Forma Scientific) to accomplish anaerobic growth.

Stress response studies. To produce the cells for stress response experiments, $40 \mathrm{l}$ of filter-sterilized whey was inoculated with $4 \mathrm{l}$ of an overnight whey culture of CNBL 1156 and incubated at $46^{\circ} \mathrm{C}$ in a fermenter (Chemap). The $\mathrm{pH}$ was maintained at $5 \cdot 6$ by addition of $\mathrm{NH}_{3}$. After $4 \mathrm{~h}$, when cell density reached $3 \times 10^{8}$ c.f.u. $\mathrm{ml}^{-1}$, the culture was divided into 27 different samples (1.4 l each). One sample, used as control, was immediately frozen in liquid nitrogen. The various stress conditions were applied to the remaining 26 samples, according to the experimental design shown in Table 1 . The $\mathrm{pH}$ was modified at the defined values of $3 \cdot 2,3 \cdot 8,4 \cdot 4,5 \cdot 0$ and $5 \cdot 6$ by adding lactic acid to the whey cultures while $\mathrm{NaCl}$ was added to final concentrations of $0 \cdot 1,0 \cdot 3,0 \cdot 5,0 \cdot 7,0 \cdot 9 \mathrm{M}$.
Oxidative stress was achieved by adding five different concentrations of $\mathrm{H}_{2} \mathrm{O}_{2}$, from 0.001 to $0.013 \%$, in a range which has been already demonstrated to induce a cellular response in Lactobacillus helveticus (Smeds et al., 1998). After $100 \mathrm{~min}$ of incubation at the temperatures defined by the CCD $(38,42,46$, 50 and $54^{\circ} \mathrm{C}$ ) the cells were harvested by centrifugation $(5000 \mathrm{~g}, 10 \mathrm{~min})$, washed twice with $50 \mathrm{mM}$ Tris/ $\mathrm{HCl}(\mathrm{pH} 7)$, frozen in liquid nitrogen and stored at $-80^{\circ} \mathrm{C}$. Cell viability was verified at the end of the stress period by plating of cultures onto MRS agar plates.

Fatty acid analysis. Lipid extraction was performed according to the method of Suutari et al. (1990). Fatty acid methyl esters were prepared by incubating the lipid extracts at $45^{\circ} \mathrm{C}$ for $15 \mathrm{~min}$ in boron trifluoride/methanol according to the method of Morrison \& Smith (1964). The fatty acid methyl esters were extracted with hexane. The relative percentages of the fatty acids were determined from the peak areas of the methyl esters using a DP 700 integrator (Spectra Physics). The results are means of three independent experiments. The coefficients of variability, expressed as the percentage ratios between the standard deviations and the mean values, ranged between 2 and $5 \%$. The unsaturation degree $(\Delta / \mathrm{mol})$ in the lipid fraction was calculated as shown in equation 1 :

$\Delta / \mathrm{mol}=[$ percentage monoenes

+2 (percentage dienes)

+3 (percentage trienes)]/100

Lactobacillic acid and the epoxides were not included in this calculation.

The mean fatty acid chain length was expressed as shown in equation 2:

Mean chain length $=\Sigma(\mathrm{FAP} \times \mathrm{C}) / 100$

where FAP is the percentage of fatty acid and $\mathrm{C}$ the number of carbon atoms.

For GC analyses, a Carlo Erba HRGR 5660 MEGA Series gas chromatograph (Carlo Erba Instruments) equipped with a flame-ionization detector and a $30 \mathrm{~m} \times 0.32 \mathrm{~mm}$ i.d. fused silica capillary column coated with a $0 \cdot 2 \mu \mathrm{m}$ film of Carbowax (Supelco) as stationary phase was used. The conditions were as follows: injector temperature, $220^{\circ} \mathrm{C}$; detector tempera-

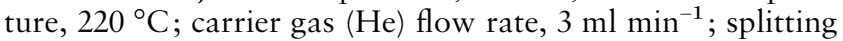
ratio, $1: 100(\mathrm{v} / \mathrm{v})$. The oven temperature was programmed from 60 to $220^{\circ} \mathrm{C}$ at $4{ }^{\circ} \mathrm{C} \mathrm{min}{ }^{-1}$. For peak identification, standard solution (Supelco) and GC/MS were used. For this a Fision HRGC MEGA Series gas chromatograph (Fision Instruments) equipped with a split-splitless injector and connected to a spectrometer (Carlo Erba QMD 1000; Carlo Erba Instruments) was used. A fused silica capillary column with a $0 \cdot 10 \mu \mathrm{m}$ methyl silicon (Chrompack) stationary phase was used. The carrier gas was He. The oven temperature was programmed from 60 to $220^{\circ} \mathrm{C}$ at $4{ }^{\circ} \mathrm{C} \mathrm{min}^{-1}$.

Statistical analysis. The aim of statistical analysis was to describe the effects of $\mathrm{pH}, \mathrm{NaCl}, \mathrm{H}_{2} \mathrm{O}_{2}$ concentrations and temperature on the fatty acid composition of Lactobacillus helveticus. A software package (Statistica for Windows; Statsoft) was used to fit the second order model to the independent variables. The variables with a significance lower than $95 \%(P>0.05)$ were not included in the final models. These models permitted the evaluation of the effects of the linear, quadratic and interactive terms of the independent variables on the chosen dependent variables. Threedimensional plots were drawn to illustrate the main and interactive effects of the independent variables on the dependent ones. They were drawn imposing constant values (i.e. the central points of the interval taken into consideration) to two of the independent variables of the CCD. 


\section{RESULTS}

\section{Modification of the cell fatty acid composition of Lactobacillus helveticus in relation to chemico-physical conditions}

In Table 2 the relative percentages of the cell fatty acids which presented the most relevant changes in relation to the combinations of factors of the CCD are reported. Table 2 also includes the composition of cellular fatty acids of the mother cell culture. The transfer and incubation of exponential phase cells of Lactobacillus helveticus for $100 \mathrm{~min}$ in whey samples in which $\mathrm{pH}$, $\mathrm{H}_{2} \mathrm{O}_{2}, \mathrm{NaCl}$ and temperature were modulated according to a CCD (Table 1) induced significant changes in the cell lipids. Under the different conditions the fatty acid profiles included components such as sebacic acid (decanedioic acid) and an epoxide of linoleic acid, vernolic acid (cis-12,13-epoxy-cis-9-octadecenoic) which have not previously been reported in LAB or other bacteria. Their identification was performed by means of GC/MS in comparison with pure standards. In GC and GC/MS profiles of some runs, two cis-trans isomeric forms of the epoxide of linoleic acid were observed. In fact, two molecules having similar retention times and very similar mass spectra were detected. The ratio between the two peak areas was about $1 / 10$ $1 / 20$. The principal component was also identified as vernolic acid by comparison with the pure molecule.

Table 2. Principal fatty acids content of Lactobacillus helveticus cells in relation to stress conditions applied according to the CCD

The fatty acids content of Lactobacillus helveticus cells not subjected to stress conditions (mother culture) are included. The reported relative percentages were calculated with respect to the total fatty acid methyl esters. The data are means of three independent experiments. The coefficients of variability ranged between 2 and $5 \%$.

\begin{tabular}{|c|c|c|c|c|c|c|c|c|c|c|c|c|c|}
\hline \multirow[t]{2}{*}{ Run } & \multicolumn{13}{|c|}{ Fatty $\operatorname{acid}(\%)^{*}$} \\
\hline & C10:0 & C12:0 & $\begin{array}{c}\text { Sebacic } \\
\text { acid }\end{array}$ & $\mathrm{C} 14: 0$ & $\mathrm{C} 16: 0$ & C16: 1 & C18:0 & $\begin{array}{c}\text { C18: } \\
1 \Delta 9\end{array}$ & $\begin{array}{l}\text { C18: } \\
1 \Delta 11\end{array}$ & $\mathrm{C} 18: 2$ & C19cyc11 & $\mathrm{C} 20: 1$ & $\begin{array}{c}\text { Vernolic } \\
\text { acid }\end{array}$ \\
\hline 1 & $0 \cdot 49$ & $1 \cdot 83$ & $0 \cdot 00$ & $10 \cdot 94$ & $32 \cdot 88$ & $2 \cdot 09$ & $11 \cdot 90$ & $17 \cdot 28$ & $4 \cdot 32$ & $5 \cdot 93$ & $2 \cdot 49$ & 0.57 & $5 \cdot 71$ \\
\hline 2 & $0 \cdot 00$ & $0 \cdot 00$ & $0 \cdot 00$ & $6 \cdot 71$ & $22 \cdot 68$ & $1 \cdot 72$ & $7 \cdot 67$ & $12 \cdot 53$ & $1 \cdot 62$ & $4 \cdot 15$ & $2 \cdot 76$ & $0 \cdot 00$ & $37 \cdot 89$ \\
\hline 3 & $0 \cdot 19$ & $1 \cdot 35$ & $0 \cdot 02$ & $12 \cdot 32$ & $34 \cdot 38$ & $2 \cdot 50$ & $9 \cdot 59$ & $16 \cdot 06$ & $4 \cdot 01$ & 0.79 & $13 \cdot 60$ & $0 \cdot 80$ & $1 \cdot 90$ \\
\hline 4 & $0 \cdot 45$ & $1 \cdot 76$ & $0 \cdot 00$ & $10 \cdot 17$ & $32 \cdot 15$ & $1 \cdot 95$ & $13 \cdot 40$ & $24 \cdot 06$ & $1 \cdot 52$ & $6 \cdot 66$ & $1 \cdot 72$ & $0 \cdot 64$ & $2 \cdot 01$ \\
\hline 5 & $0 \cdot 40$ & $1 \cdot 46$ & $0 \cdot 37$ & $9 \cdot 83$ & $28 \cdot 24$ & $2 \cdot 09$ & $9 \cdot 58$ & $17 \cdot 47$ & $2 \cdot 31$ & $4 \cdot 82$ & 3.93 & $1 \cdot 05$ & $13 \cdot 01$ \\
\hline 6 & $0 \cdot 00$ & $2 \cdot 25$ & $0 \cdot 00$ & $14 \cdot 08$ & $39 \cdot 08$ & $2 \cdot 57$ & $10 \cdot 70$ & $14 \cdot 48$ & $2 \cdot 99$ & $3 \cdot 75$ & $4 \cdot 61$ & $0 \cdot 00$ & $0 \cdot 00$ \\
\hline 7 & $0 \cdot 44$ & $1 \cdot 61$ & $0 \cdot 00$ & $12 \cdot 42$ & $32 \cdot 50$ & $2 \cdot 40$ & $8 \cdot 70$ & $13 \cdot 75$ & $2 \cdot 96$ & $4 \cdot 15$ & $5 \cdot 96$ & $0 \cdot 47$ & $9 \cdot 45$ \\
\hline 8 & $0 \cdot 00$ & $2 \cdot 06$ & $0 \cdot 00$ & $14 \cdot 87$ & $39 \cdot 84$ & $2 \cdot 58$ & $10 \cdot 95$ & $13 \cdot 01$ & $2 \cdot 90$ & $3 \cdot 62$ & $5 \cdot 17$ & $0 \cdot 00$ & $0 \cdot 00$ \\
\hline 9 & $0 \cdot 88$ & $2 \cdot 14$ & $0 \cdot 00$ & $13 \cdot 37$ & $36 \cdot 44$ & 3.98 & $8 \cdot 84$ & $13 \cdot 67$ & $3 \cdot 42$ & 0.72 & $10 \cdot 85$ & 0.45 & $2 \cdot 68$ \\
\hline 10 & 0.00 & $1 \cdot 14$ & $0 \cdot 00$ & $10 \cdot 07$ & $31 \cdot 51$ & $2 \cdot 11$ & 11.59 & $19 \cdot 76$ & 4.94 & 6.69 & $2 \cdot 91$ & $0 \cdot 61$ & 4.97 \\
\hline 11 & 0.59 & 1.99 & $0 \cdot 00$ & $10 \cdot 82$ & $32 \cdot 28$ & 1.93 & $11 \cdot 54$ & $20 \cdot 58$ & $1 \cdot 32$ & $4 \cdot 89$ & $1 \cdot 64$ & $0 \cdot 46$ & $8 \cdot 27$ \\
\hline 12 & $0 \cdot 67$ & $1 \cdot 58$ & $0 \cdot 00$ & $12 \cdot 22$ & $34 \cdot 00$ & $4 \cdot 49$ & $9 \cdot 25$ & $14 \cdot 74$ & $3 \cdot 68$ & $4 \cdot 88$ & $4 \cdot 01$ & 0.78 & $4 \cdot 02$ \\
\hline 13 & $0 \cdot 00$ & $1 \cdot 76$ & $0 \cdot 00$ & $11 \cdot 78$ & $32 \cdot 00$ & $2 \cdot 19$ & $9 \cdot 32$ & $13 \cdot 92$ & $3 \cdot 48$ & $4 \cdot 58$ & $4 \cdot 58$ & $1 \cdot 53$ & $11 \cdot 30$ \\
\hline 14 & $0 \cdot 00$ & $0 \cdot 97$ & $0 \cdot 00$ & $9 \cdot 22$ & $29 \cdot 27$ & $2 \cdot 51$ & $9 \cdot 04$ & $14 \cdot 25$ & $2 \cdot 89$ & $4 \cdot 78$ & 6.77 & 0.05 & $15 \cdot 14$ \\
\hline 15 & 0.06 & $1 \cdot 48$ & $0 \cdot 00$ & $11 \cdot 39$ & $29 \cdot 56$ & $3 \cdot 01$ & $8 \cdot 87$ & $14 \cdot 87$ & $3 \cdot 83$ & $4 \cdot 87$ & $7 \cdot 71$ & $0 \cdot 06$ & $9 \cdot 19$ \\
\hline 16 & $0 \cdot 51$ & 1.74 & $0 \cdot 00$ & $13 \cdot 19$ & $33 \cdot 83$ & $3 \cdot 27$ & $9 \cdot 35$ & $13 \cdot 95$ & $3 \cdot 49$ & $4 \cdot 60$ & $4 \cdot 56$ & 0.06 & $6 \cdot 56$ \\
\hline 17 & $3 \cdot 03$ & 0.58 & $3 \cdot 51$ & $14 \cdot 47$ & $41 \cdot 73$ & $1 \cdot 05$ & $8 \cdot 43$ & $9 \cdot 84$ & $2 \cdot 46$ & 0.00 & $0 \cdot 00$ & $2 \cdot 19$ & $5 \cdot 06$ \\
\hline 18 & 0.79 & $1 \cdot 72$ & $0 \cdot 44$ & $13 \cdot 27$ & $31 \cdot 74$ & $3 \cdot 07$ & $7 \cdot 62$ & $12 \cdot 96$ & $3 \cdot 02$ & $4 \cdot 21$ & $5 \cdot 90$ & 0.93 & $4 \cdot 05$ \\
\hline 19 & $1 \cdot 10$ & $1 \cdot 63$ & $0 \cdot 00$ & $11 \cdot 03$ & $32 \cdot 43$ & $2 \cdot 57$ & $10 \cdot 69$ & $20 \cdot 75$ & $1 \cdot 83$ & $6 \cdot 52$ & $6 \cdot 22$ & $0 \cdot 61$ & $2 \cdot 81$ \\
\hline 20 & $0 \cdot 62$ & $14 \cdot 24$ & $0 \cdot 00$ & $11 \cdot 26$ & $30 \cdot 98$ & $2 \cdot 70$ & $7 \cdot 75$ & $12 \cdot 04$ & $3 \cdot 01$ & $3 \cdot 54$ & 8.02 & 0.45 & $2 \cdot 74$ \\
\hline 21 & 0.57 & 1.98 & $0 \cdot 00$ & $15 \cdot 76$ & $36 \cdot 20$ & $3 \cdot 48$ & $7 \cdot 02$ & $11 \cdot 00$ & $3 \cdot 81$ & $3 \cdot 64$ & $7 \cdot 35$ & $0 \cdot 45$ & $3 \cdot 19$ \\
\hline 22 & $0 \cdot 49$ & 1.95 & $0 \cdot 00$ & $12 \cdot 90$ & $34 \cdot 58$ & $3 \cdot 07$ & $9 \cdot 42$ & $15 \cdot 57$ & $2 \cdot 71$ & $4 \cdot 86$ & 4.78 & $0 \cdot 46$ & $4 \cdot 32$ \\
\hline 23 & $0 \cdot 46$ & $1 \cdot 76$ & $0 \cdot 00$ & $13 \cdot 84$ & $34 \cdot 09$ & $5 \cdot 68$ & 6.79 & $11 \cdot 17$ & $2 \cdot 79$ & $0 \cdot 80$ & $14 \cdot 42$ & 0.52 & $4 \cdot 20$ \\
\hline 24 & $1 \cdot 65$ & $1 \cdot 85$ & $0 \cdot 00$ & $10 \cdot 12$ & $32 \cdot 03$ & $2 \cdot 21$ & $13 \cdot 56$ & $22 \cdot 21$ & $2 \cdot 17$ & $6 \cdot 23$ & $2 \cdot 75$ & 0.47 & $0 \cdot 71$ \\
\hline 25 & $0 \cdot 41$ & $1 \cdot 83$ & $0 \cdot 00$ & $14 \cdot 08$ & $33 \cdot 87$ & 3.44 & $7 \cdot 55$ & $11 \cdot 46$ & $3 \cdot 72$ & $4 \cdot 02$ & 8.86 & 0.47 & $2 \cdot 98$ \\
\hline 26 & $0 \cdot 68$ & $1 \cdot 84$ & $0 \cdot 00$ & $14 \cdot 11$ & $37 \cdot 41$ & 3.49 & $7 \cdot 92$ & $10 \cdot 41$ & $4 \cdot 05$ & $3 \cdot 27$ & $7 \cdot 24$ & 0.40 & $1 \cdot 86$ \\
\hline $\begin{array}{l}\text { Mother } \\
\text { culture }\end{array}$ & 0.56 & $1 \cdot 68$ & $0 \cdot 00$ & $11 \cdot 33$ & $32 \cdot 07$ & $2 \cdot 32$ & $10 \cdot 96$ & $19 \cdot 72$ & $2 \cdot 18$ & $6 \cdot 17$ & $3 \cdot 92$ & 0.56 & $4 \cdot 24$ \\
\hline
\end{tabular}

* The fatty acyl residues are: $n$-decanoic acid (C10:0), decanedioic acid (sebacic acid), dodecanoic acid (C12:0), tetradecanoic acid (C14:0), hexadecanoic acid (C16:0), cis-9-hexadecenoic acid (C16:1), octadecanoic acid (C18:0), cis-9-octadecenoic acid (C18:149),

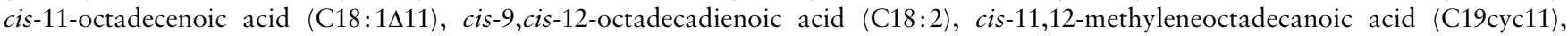
cis-icos-9-enoic acid (C20:1) and vernolic acid (cis-12,13-epoxy-cis-octadec-9-enoic acid). 
Table 3. Best fit equations relative to the individual, quadratic and interactive effects of variables such as $\mathrm{H}_{2} \mathrm{O}_{2}$ concentration, temperature, $\mathrm{pH}$ and $\mathrm{NaCl}$ concentration on individual fatty acid percentages, unsaturation level (UL) and mean chain length $(\mathrm{CL})$ of Lactobacillus helveticus cells

Only the terms with $P<0.05$ were included. The fatty acyl residues are: tetradecanoic acid (C14:0), pentadecanoic acid (C15:0), hexadecanoic acid (C16:0), cis-9-hexadecenoic acid (C16:1), heptadecanoic acid (C17:0), octadecanoic acid (C18:0), cis-9-

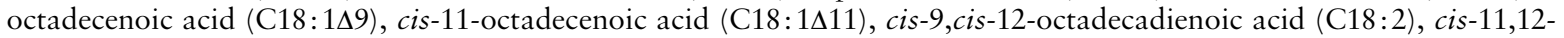
methyleneoctadecanoic acid (C19cyc11), cis-icos-9-enoic acid (C20:1) and vernolic acid (cis-12,13-epoxy-cis-octadec-9-enoic acid).

\begin{tabular}{|c|c|c|c|c|}
\hline Equation* & & $\begin{array}{l}\text { Regression } \\
\text { coefficient }\end{array}$ & F-value & $\begin{array}{l}\text { Standard } \\
\text { error }\end{array}$ \\
\hline $1(\mathrm{C} 14: 0)$ & $\begin{aligned}= & 0 \cdot 23[\mathrm{~T}]-2794 \cdot 12\left[\mathrm{H}_{2} \mathrm{O}_{2}\right]+60 \cdot 07[\mathrm{NaCl}]+47 \cdot 92[\mathrm{~T}]\left[\mathrm{H}_{2} \mathrm{O}_{2}\right] \\
& -1 \cdot 29[\mathrm{~T}][\mathrm{NaCl}]+156 \cdot 09[\mathrm{pH}]\left[\mathrm{H}_{2} \mathrm{O}_{2}\right]\end{aligned}$ & $0 \cdot 992$ & $209 \cdot 95$ & $1 \cdot 74$ \\
\hline $2(\mathrm{C} 15: 0)$ & $=0 \cdot 452[\mathrm{pH}]-0 \cdot 0387[\mathrm{pH}]^{2}$ & $0 \cdot 982$ & $337 \cdot 67$ & $0 \cdot 24$ \\
\hline $3(\mathrm{C} 16: 0)$ & $\begin{aligned}= & 0 \cdot 63[\mathrm{~T}]-4572 \cdot 88\left[\mathrm{H}_{2} \mathrm{O}_{2}\right]+120 \cdot 94[\mathrm{NaCl}]+101 \cdot 87[\mathrm{~T}]\left[\mathrm{H}_{2} \mathrm{O}_{2}\right] \\
& -2 \cdot 61[\mathrm{~T}][\mathrm{NaCl}]\end{aligned}$ & $0 \cdot 996$ & $514 \cdot 23$ & $3 \cdot 35$ \\
\hline $4(\mathrm{C} 16: 1)$ & $=0 \cdot 0734[\mathrm{~T}]-10 \cdot 61[\mathrm{NaCl}]+7 \cdot 47[\mathrm{NaCl}]^{2}+1 \cdot 18[\mathrm{NaCl}][\mathrm{pH}]$ & $0 \cdot 966$ & $78 \cdot 69$ & $0 \cdot 81$ \\
\hline $5(\mathrm{C} 17: 0)$ & $\begin{aligned}= & -350 \cdot 7\left[\mathrm{H}_{2} \mathrm{O}_{2}\right]+5 \cdot 67[\mathrm{NaCl}]+0 \cdot 00023[\mathrm{~T}]^{2}+7 \cdot 46[\mathrm{~T}]\left[\mathrm{H}_{2} \mathrm{O}_{2}\right] \\
& -0 \cdot 121[\mathrm{~T}][\mathrm{NaCl}]\end{aligned}$ & $0 \cdot 953$ & $41 \cdot 58$ & $0 \cdot 18$ \\
\hline $6(\mathrm{C} 18: 0)$ & $\begin{aligned}= & 27 \cdot 28[\mathrm{NaCl}]+0 \cdot 013[\mathrm{~T}]^{2}+1 \cdot 46[\mathrm{pH}]^{2}-0 \cdot 235[\mathrm{~T}][\mathrm{pH}] \\
& -6 \cdot 41[\mathrm{NaCl}][\mathrm{pH}]\end{aligned}$ & $0 \cdot 992$ & $289 \cdot 07$ & $1 \cdot 30$ \\
\hline $7(\mathrm{C} 18: 1 \Delta 9)$ & $\begin{aligned}= & 44 \cdot 7[\mathrm{NaCl}]+0 \cdot 03[\mathrm{~T}]^{2}+3 \cdot 6[\mathrm{pH}]^{2}-0 \cdot 55[\mathrm{~T}][\mathrm{pH}] \\
& +1457 \cdot 6\left[\mathrm{H}_{2} \mathrm{O}_{2}\right][\mathrm{NaCl}]-190 \cdot 0\left[\mathrm{H}_{2} \mathrm{O}_{2}\right][\mathrm{pH}]-13 \cdot 4[\mathrm{pH}][\mathrm{NaCl}]\end{aligned}$ & $0 \cdot 990$ & $146 \cdot 04$ & $2 \cdot 45$ \\
\hline $8(\mathrm{C} 18: 1 \Delta 11)$ & $\begin{aligned}= & 0 \cdot 31[\mathrm{~T}]-1010 \cdot 31\left[\mathrm{H}_{2} \mathrm{O}_{2}\right]-0 \cdot 07[\mathrm{~T}][\mathrm{pH}]-494 \cdot 5\left[\mathrm{H}_{2} \mathrm{O}_{2}\right][\mathrm{NaCl}] \\
& +281 \cdot 5\left[\mathrm{H}_{2} \mathrm{O}_{2}\right][\mathrm{pH}]+1 \cdot 21[\mathrm{NaCl}][\mathrm{pH}]\end{aligned}$ & $0 \cdot 980$ & $79 \cdot 81$ & $0 \cdot 72$ \\
\hline $9(\mathrm{C} 18: 2)$ & $=0 \cdot 015[\mathrm{~T}]^{2}+1 \cdot 46[\mathrm{pH}]^{2}-0 \cdot 28[\mathrm{~T}][\mathrm{pH}]$ & $0 \cdot 935$ & $53 \cdot 55$ & $1 \cdot 69$ \\
\hline 10 (C19сус 11$)$ & $=10 \cdot 87[\mathrm{NaCl}]$ & $0 \cdot 860$ & $70 \cdot 75$ & $3 \cdot 47$ \\
\hline $11(\mathrm{C} 20: 1)$ & $=0 \cdot 123[\mathrm{pH}]$ & $0 \cdot 745$ & $31 \cdot 28$ & $0 \cdot 50$ \\
\hline 12 (vernolic acid) & $\begin{aligned}= & 18642 \cdot 8\left[\mathrm{H}_{2} \mathrm{O}_{2}\right]-238 \cdot 0[\mathrm{NaCl}]-269 \cdot 3\left[\mathrm{H}_{2} \mathrm{O}_{2}\right][\mathrm{T}]+3 \cdot 2[\mathrm{~T}][\mathrm{NaCl}] \\
& +0 \cdot 04[\mathrm{~T}][\mathrm{pH}]-1386 \cdot 7\left[\mathrm{H}_{2} \mathrm{O}_{2}\right][\mathrm{pH}]+19 \cdot 4[\mathrm{NaCl}][\mathrm{pH}]\end{aligned}$ & $0 \cdot 871$ & $8 \cdot 53$ & $5 \cdot 58$ \\
\hline 13 (UL) & $\begin{aligned}= & 0 \cdot 093[\mathrm{pH}]+0 \cdot 0007[\mathrm{~T}]^{2}+0 \cdot 053[\mathrm{pH}]^{2}-0 \cdot 406[\mathrm{~T}]\left[\mathrm{H}_{2} \mathrm{O}_{2}\right] \\
& -0 \cdot 011[\mathrm{pH}][\mathrm{T}]+34 \cdot 44[\mathrm{NaCl}]\left[\mathrm{H}_{2} \mathrm{O}_{2}\right]-0 \cdot 07[\mathrm{pH}][\mathrm{NaCl}]\end{aligned}$ & $0 \cdot 992$ & $175 \cdot 07$ & $0 \cdot 04$ \\
\hline $14(\mathrm{CL})$ & $=0 \cdot 38[\mathrm{~T}]+3 \cdot 59[\mathrm{pH}]-0.086[\mathrm{pH}][\mathrm{T}]$ & $0 \cdot 999$ & $16633 \cdot 0$ & $0 \cdot 37$ \\
\hline
\end{tabular}

* $[\mathrm{T}]$, Temperature $\left({ }^{\circ} \mathrm{C}\right) ;[\mathrm{NaCl}], \mathrm{NaCl}$ concentration $(\mathrm{M}) ;\left[\mathrm{H}_{2} \mathrm{O}_{2}\right], \mathrm{H}_{2} \mathrm{O}_{2}$ concentration $(\%) ;[\mathrm{pH}]$, pH level.

However, in runs 6 and 8 there was a shift in the GC peak, suggesting that just the trans isomer was present. The reference trans isomer is not available commercially. Therefore, as the identification was only presumptive it was not considered in the calculation of the relative percentages. Traces of other trans UFAs were evident as small shoulders in some GC profiles. According to Keweloh \& Heipieper (1996), the trans fatty acids are synthesized by a direct isomerization of cis UFAs in plasma membranes. This isomerization is regarded as an alternative mechanism to modify membrane fluidity and a relevant parameter to indicate exposure to toxic molecules (Keweloh \& Heipieper, 1996). Because their proportion was lower than $0.5 \%$, they were not included in Table 2 . Relevant proportions of linoleic acid, which is rarely reported in LAB (Dionisi et al., 1999), were present under certain conditions.

The proportion of some fatty acids, and particularly vernolic acid, presented a large variability within the cell samples exposed to the various combinations of factors. Cyclopropane fatty acids (CFA) such as dihydrosterculic (cis-9,10-methyleneoctadecanoic) and lactobacillic (cis11,12-methyleneoctadecanoic) acids are regarded by many authors as the major fatty acids in LAB (Suutari \& Laakso, 1992; Dionisi et al., 1999). However, in this study only lactobacillic acid was found, at levels up to $14 \cdot 4 \%$. Moreover, this fatty acid is regarded to play an important role under acidic conditions and at low temperatures (Brown et al., 1997). The relatively low availability of oleic acid (accounting for $1.87 \%$ of the whey lipid fraction) in the whey may explain this peculiarity. The principal fatty acids of the whey were stearic $(41.73 \%)$, palmitic $(13 \cdot 81)$, myrystic $(9 \cdot 58 \%)$ and lauric acids $(4 \cdot 26 \%)$. In fact, it has been reported that oleic acid supplementation, e.g. addition of Tween 80 to MRS medium, is the limiting factor for cyclopropane fatty acid inclusion in cell fatty acids (Johnsson et al., 1995).

The odd fatty acids were present in traces in all the samples and were not subjected to remarkable changes under the various conditions. The branched fatty acids are in fact regarded as having an important role principally in the adaptation to low temperatures. Sebacic acid was present just in some runs of the CCD. Although the odd-numbered and branched fatty acids are typical for example in the genus Bacillus, they have 
also been reported in LAB (Dykes et al., 1995), Listeria monocytogenes and other species or microbial group, including Clostridium botulinum (Evans et al., 1998). However, although the increase in both the total branched-chain and iso/anteiso branched ratio have been documented, the regulation of such changes is not well understood. In $B$. subtilis a relative increase in the proportion of iso-branched fatty acids has been associated with temperature increase (Van de Vossenberg et al., 1999). Although it is impossible to correlate its increase to a single factor, vernolic acid was present particularly at low $\mathrm{pH}$ values in combination with a high $\mathrm{H}_{2} \mathrm{O}_{2}$ concentration. In fact, it accounted for $37 \%$ of the total fatty acids in run 2 , corresponding to cells exposed to a $\mathrm{pH}$ of $3 \cdot 8$, an incubation temperature of $42{ }^{\circ} \mathrm{C}, 0.013 \% \mathrm{H}_{2} \mathrm{O}_{2}$ and $0.3 \mathrm{M} \mathrm{NaCl}$. However, a key role in the response mechanisms can be attributed to the fate of oleic acid incorporated in the phospholipids. Its proportion increased with temperature, probably due to desaturation of stearic acid (octadecanoic acid). However, as a response to different physico-chemical perturbations, it could be competitively converted in situ into lactobacillic acid by cyclization, or into linoleic acid by desaturation. In fact, in the cells of runs 3, 9 and 23 , characterized by a high proportion of lactobacillic acid, linoleic acid was present at a very low proportion. The absence of vernolic acid in runs 6 and 8, characterized by relatively high levels of $\mathrm{H}_{2} \mathrm{O}_{2}$, may appear surprising. However, as indicated above, a high proportion of the trans isomer of the epoxide of linoleic acid was presumptively identified in their GC and GC/MS profiles.

The values of the individual fatty acid percentages were analysed to obtain polynomial equations, describing the individual or interactive effects of the independent variables of the CCD on their proportion in the cell lipids. The best fit equations obtained are reported in Table 3. The unsaturation level was the most important response to the various combinations of sublethal stresses applied as shown by equation 13 of Table 3. In particular it was positively affected by the $\mathrm{pH}$, as individual and quadratic terms, by the temperature as a quadratic term and by the combination of oxidative and osmotic stress. On the other hand, it was negatively affected by the combination of oxidative and temperature stress, the combination of temperature and acid stress and the combination of acid and osmotic stress. Fig. 1 shows how the unsaturation level was affected both by the temperature increase and by $\mathrm{H}_{2} \mathrm{O}_{2}$ concentration. The simultaneous application of high levels of temperature and $\mathrm{H}_{2} \mathrm{O}_{2}$ induced decrease of this variable.

All the individual UFAs were positively affected by temperature increase as individual or quadratic terms except gladoleic acid (cis-9-icosenoic acid) (equation 11, Table 3). The equation relative to myristoleic acid (cis9-tetradecenoic acid) was not significant and, consequently, it was not included in Table 3.

The oleic acid relative percentage increased remarkably (equation 7, Table 3) with temperature increase and in

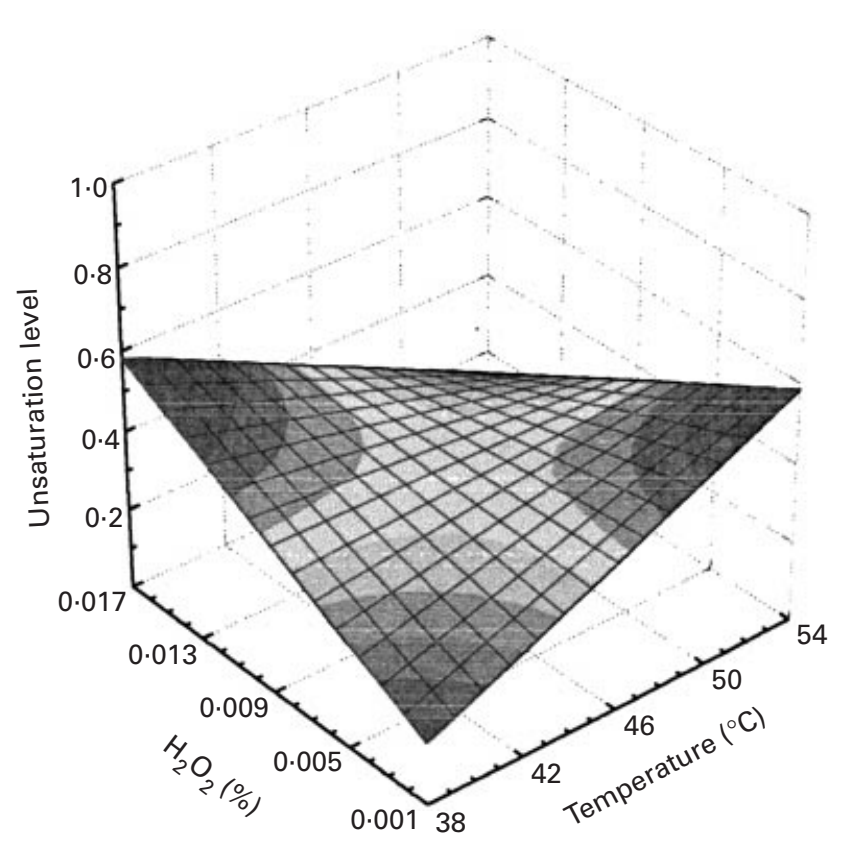

Fig. 1. Effects of the combination of oxidative and temperature stress on the fatty acid unsaturation level in Lactobacillus helveticus.

the presence of multiple stress factors, such as low $\mathrm{pH}$ and high $\mathrm{NaCl}$ concentration. The effects of the combination of acid and osmotic stress and the combination of oxidative and temperature stress on the relative percentages of oleic acid are shown in Fig. 2(a) and (b). However, it was not affected by oxidative stress. Vaccenic acid (cis-11-octadecenoic acid), which typically arises from anaerobic C2 elongation of palmitoleic acid (cis-9-hexadecenoic acid) (Keweloh \& Heipieper, 1996), appeared to be the sole fatty acid, in addition to vernolic acid, whose percentage increased with $\mathrm{H}_{2} \mathrm{O}_{2}$ as an individual factor, as indicated by equation 8 (Table 3 ). The common origin of linoleic and vernolic, as well as lactobacillic acid from oleic acid associated with membrane phospholipids makes it necessary to consider the changes of such an individual fatty acid in an integrated manner. The various equations obtained support the hypothesis of the alternative conversion of the oleic acid into linoleic, vernolic or lactobacillic acid. In fact, the conditions which are shown to induce a drastic diminution of vernolic acid (low $\mathrm{pH}$ and high $\mathrm{NaCl}$ concentration) lead to a lactobacillic acid increase (equations 9, 10, 12, Table 3). In particular, as indicated by equation 10 , the relative proportion of lactobacillic acid increased only with increasing $\mathrm{NaCl}$ concentrations.

Linoleic acid, an uncommon fatty acid in LAB (Guillot et al., 2000; Suutari \& Laakso, 1992; Lonvaud-Funel \& Desens, 1990; Ratledge \& Wilkinson, 1989), was present in all combinations. Its dependence on the various independent variables of CCD was coherent with that of the other UFAs. Its proportion increased with the quadratic terms of temperature and $\mathrm{pH}$ (equation 9, 
(a)

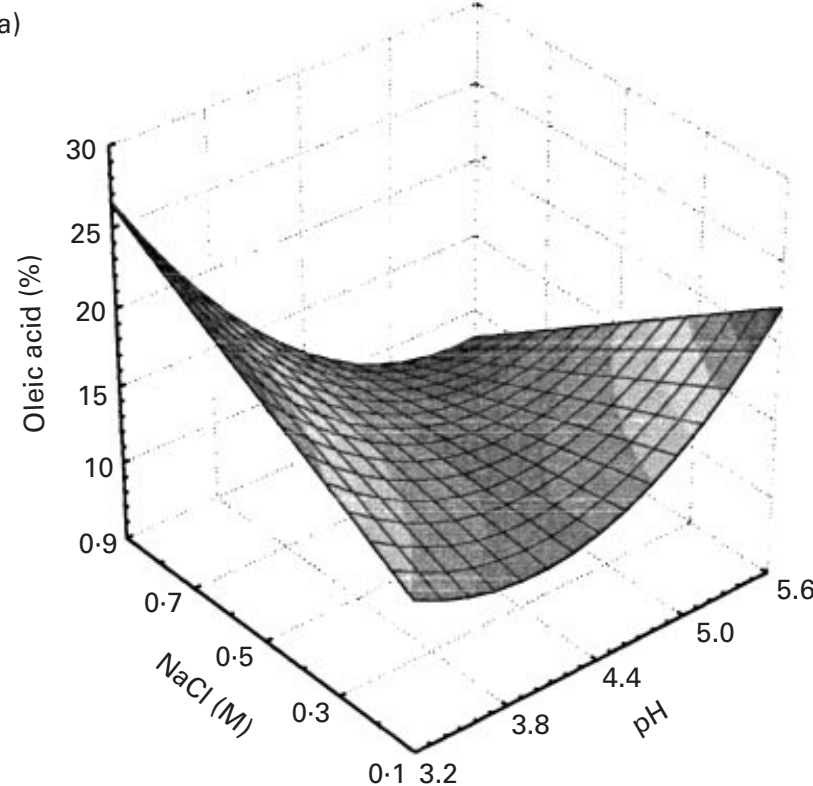

(b)

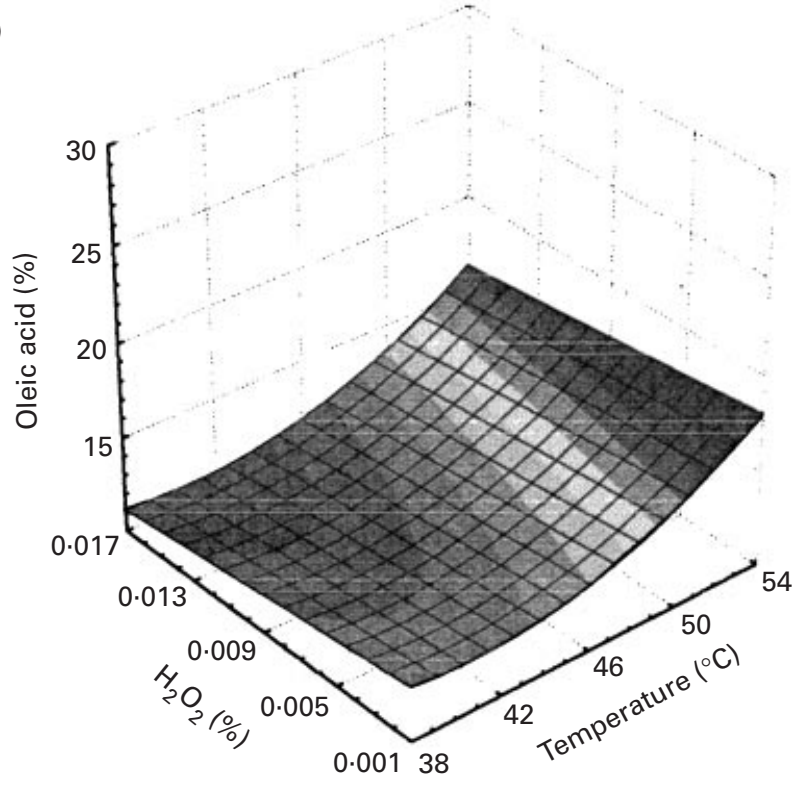

Fig. 2. Effects of (a) the combination of osmotic and acid stress and (b) the combination of oxidative and temperature stress on oleic acid (percentage of total fatty acids) in Lactobacillus helveticus.

Table 3) and was significantly affected by the combination of temperature and acid stress (Fig. 3a). Equation 12 (Table 3) describes the effects of the independent variables of the CCD and their interaction on the vernolic acid relative percentages. Its formation was positively affected by $\mathrm{H}_{2} \mathrm{O}_{2}$ concentration and was reduced by $\mathrm{NaCl}$ concentration. As indicated in Fig. $3(\mathrm{~b})$, relative to the combination of oxidative and temperature stress, the vernolic acid proportion increased with the increase of these two variables. However, its presence decreased when they were at their
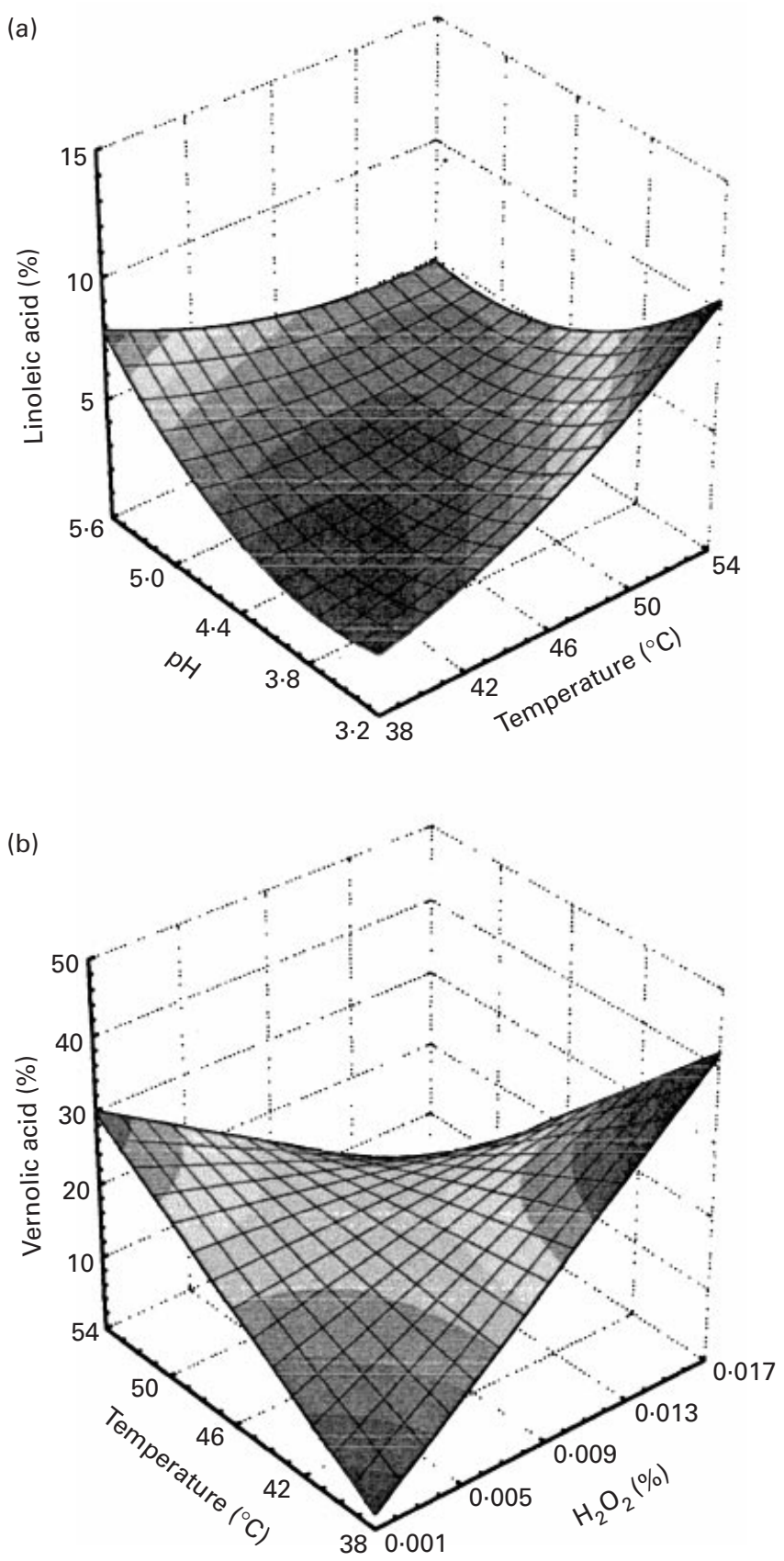

Fig. 3. Effects of the combination of acid and temperature stress and the combination of oxidative and temperature stress, respectively, on (a) linoleic acid and (b) vernolic acid (percentage of total fatty acids) in Lactobacillus helveticus.

maximum values. A possible interpretation is that under these conditions the epoxides, and particularly vernolic acid, can be further rapidly converted into aldehyde and hydrocarbons and eliminated. However, this epoxide also occurred in the control cells grown on whey at $46{ }^{\circ} \mathrm{C}$.

The branched fatty acid changes correlated to physicochemical conditions were not significant and consequently the equations were not included in Table 3. 
Table 4. Selected cell fatty acid percentages of Lactobacillus helveticus in relation to incubation conditions

The reported relative percentages have been calculated with respect to the total fatty acid methyl esters. The data are means of three independent experiments. The coefficients of variability were lower than $5 \%$.

\begin{tabular}{|c|c|c|c|c|c|c|c|c|c|c|c|}
\hline \multicolumn{2}{|c|}{ Growth conditions } & \multicolumn{10}{|c|}{ Fatty acids $(\%)^{*}$} \\
\hline $\begin{array}{l}\text { Temperature } \\
\left({ }^{\circ} \mathrm{C}\right)\end{array}$ & $\mathrm{O}_{2}$ availability & C16:0 & $\mathrm{C} 16: 1$ & $\mathrm{C} 17: 0$ & $\mathrm{C} 17: 1$ & $\mathrm{C} 18: 0$ & $\begin{array}{c}\text { C18: } \\
1 \Delta 9\end{array}$ & $\begin{array}{l}\mathrm{C} 18: \\
1 \Delta 11\end{array}$ & $\mathrm{C} 18: 2$ & C20: 1 & $\begin{array}{c}\text { Vernolic } \\
\text { acid }\end{array}$ \\
\hline 42 & Anaerobiosis & $34 \cdot 81$ & $2 \cdot 91$ & $0 \cdot 64$ & $0 \cdot 44$ & $11 \cdot 52$ & $13 \cdot 45$ & $6 \cdot 47$ & $4 \cdot 94$ & $0 \cdot 60$ & $0 \cdot 81$ \\
\hline 42 & Aerobiosis & $42 \cdot 60$ & $0 \cdot 00$ & $0 \cdot 00$ & $0 \cdot 00$ & $7 \cdot 79$ & $12 \cdot 70$ & $5 \cdot 85$ & $4 \cdot 15$ & $0 \cdot 00$ & $2 \cdot 29$ \\
\hline 37 & Aerobiosis & $51 \cdot 63$ & $0 \cdot 77$ & $0 \cdot 00$ & $0 \cdot 00$ & $4 \cdot 34$ & $7 \cdot 64$ & $2 \cdot 90$ & $5 \cdot 83$ & $0 \cdot 00$ & $3 \cdot 06$ \\
\hline 37 & Anaerobiosis & $39 \cdot 41$ & $4 \cdot 60$ & $0 \cdot 96$ & $0 \cdot 00$ & $8 \cdot 26$ & $10 \cdot 38$ & $6 \cdot 14$ & $3 \cdot 26$ & $0 \cdot 42$ & $1 \cdot 21$ \\
\hline
\end{tabular}

*The fatty acyl residues are: hexadecanoic acid (C16:0), cis-9-hexadecenoic acid (C16:1), heptadecanoic acid (C17:0), cis-10-

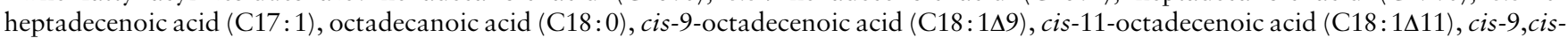
12-octadecadienoic acid (C18:2), cis-icos-9-enoic acid (C20:1) and vernolic acid (cis-12,13-epoxy-cis-octadec-9-enoic acid).

All stress combinations adopted can be regarded as sublethal as verified by plate counting (data not shown).

\section{Composition of cell fatty acids in relation to temperature and oxygen availability}

To investigate the effect of $\mathrm{O}_{2}$ availability on unsaturation and epoxide formation, the strain was grown at 37 and $42{ }^{\circ} \mathrm{C}$ under both aerobic and anaerobic conditions. In Table 4 the relative percentages of some of the fatty acids are shown. The results showed that the proportion of UFAs, such as palmitoleic, oleic, vaccenic and gladoleic acids, was higher under anaerobic conditions and confirmed that the unsaturation level was higher at 42 than at $37^{\circ} \mathrm{C}$. Moreover, at both 37 and $42{ }^{\circ} \mathrm{C}$ vernolic acid was present in the lipid extracts. However, aerobic conditions remarkably increased the epoxide proportion, supporting the hypothesis of a peroxidation of the in situ membrane-associated linoleic acid. Therefore, at the same temperature, a lower proportion of vernolic acid was associated with higher proportions of linoleic acid or other UFAs.

\section{DISCUSSION}

The cellular fatty acid composition is the result of a sum of complex phenomena maintaining optimal viability of the cell under different conditions, which makes it difficult to understand the adjustment mechanisms linking fatty acid composition to various stress factors (Suutari et al., 1990; Russell \& Fukanaga, 1990; Russell et al., 1995). However, the results obtained in this study clearly identify an increase in unsaturation level of fatty acids as a response to exposure to superoptimal temperatures. This behaviour suggests that desaturase activation or hyperinduction plays an important role in the response to heat stress at least in this thermotolerant strain. Moreover, on the basis of our results it can be hypothesized that, as a response to the physico-chemical stresses applied, the oleic acid associated with phospholipids could competitively be converted to linoleic acid (and subsequently to vernolic acid) or to lactobacillic acid. At higher temperature this latter conversion could be used to increase membrane rigidity and decrease the permeability of the membrane to $\mathrm{Na}^{+}$, protons and possibly to $\mathrm{H}_{2} \mathrm{O}_{2}$. The biosynthetic routes of fatty acids have been poorly studied in lactobacilli (Johnsson et al., 1995; Lonvaud-Funel \& Desens, 1990; Decallone et al., 1991; Suutari \& Laakso, 1992).

In lactobacilli temperature is reported to induce changes in fatty acids in relation to the regulation of the degree of fatty acid unsaturation, cyclization and proportions of long-chain fatty acids containing 20 to 24 carbons (Dionisi et al., 1999; Suutari \& Laakso, 1992). However, the range of temperatures studied has generally not exceeded the optimal ones. A comparison of literature data is not always possible since fatty acid identification is often based just on GC retention times. Moreover, fatty acid, or precursor, supplementation in culture media strongly affects cellular fatty acid profiles. In particular, oleic acid, added to MRS as Tween 80, is known to be incorporated into the LAB membrane and further converted within the membrane to the corresponding cyclopropane fatty acids. In particular, oleic (cis-9-ocatadecenoic acid) and cis-vaccenic (cis-11-octadecenoic acid) acids are methylated to form dihydrosterculic acid (9,10-methyleneoctadecenoic acid) and lactobacillic acid (11,12-methyleneoctadecanoic acid), respectively (Johnsson et al., 1995; Fulko, 1983). The role of CFA in the membrane of LAB is poorly understood. However, cyclization is generally regarded as a tool to reduce membrane fluidity and prevent the penetration of undesirable molecules. In Escherichia coli, CFA is one of the factors that protect cells from acid shock (Brown et al., 1997).

In the course of the present study the membrane fatty acid composition was studied by growing Lactobacillus helveticus CNBL 1156 in its natural environment, i.e. milk whey, without addition of Tween 80 . The increase in the unsaturation level observed at superoptimal temperatures, as well as the model obtained, provided evidence that this thermotolerant species shares this 
response to heat stress with $S$. cerevisiae, H. polymorpha and Lactococcus lactis (Guerzoni et al., 1997; Guillot et al., 2000). It should be noted that yeasts possess a whole array of defence responses against oxidative stress (Moradas-Ferreira et al., 1996), whereas Lactobacillus helveticus does not appear to harbour any of these cellular mechanisms of protection against toxic oxygen compounds such as $\mathrm{H}_{2} \mathrm{O}_{2}$. These results may support the hypothesis that, since the unsaturation of fatty acids is an oxygen-dependent reaction, the increase in the activity of the fatty acid desaturase system, induced at superoptimal temperatures, could be seen as a response mechanism that consumes oxygen and reduces free radical cellular damage. It has been reported that heat shock stimulates enzymic and non-enzymic antioxidant defences in yeasts (Piper, 1995). In fact the production of ROS (Guerzoni et al., 1997; Rees et al., 1995; Dodd et al., 1997) such as the superoxide anion increases under conditions of heat stress.

The synergistic effect of aerobic conditions and superoptimal temperatures is clearly evidenced by the increase in levels of the epoxide of linoleic acid during aerobic growth at $42^{\circ} \mathrm{C}$. The epoxides are generally further converted into degradation products such as hydrocarbons and aldehyde (Howlett \& Avery, 1997). It has been suggested that lipid peroxidation in plant and animal tissues is a mechanism under enzymic control (Spiteller, 1996). Herold \& Spiteller (1996) showed that injury in mammalian cells can activate lipoxygenases and epoxidases.

The presence of vernolic acid and other epoxides of long-chain fatty acids has not been previously reported in $\mathrm{LAB}$ and other microbes. It can be suggested that the remarkable proportion of epoxide in lipid extracts of Lactobacillus helveticus parallels the response of plant and animal tissues to injury or cell damage. In general the epoxides react readily with a great number of cell compounds, including proteins and DNA. Therefore, they have to be rapidly detoxified and eliminated by specific hydrolases or glutathione transferases (Swaving $\&$ de Bont, 1998; Leak et al., 1992). However, the dynamics of stress exposure, cell recovery and lipid extraction under these experimental conditions could have prevented the elimination of vernolic acid.

An alternative causal agent for the occurrence of epoxide in Lactobacillus helveticus grown in whey could be the enzyme lactoperoxidase. This enzyme, which occurs in milk and whey, is able to generate oxygen and shortlived singlet oxygen species (Francis et al., 1995).

The incorporation or the biosynthesis of a reactive target such as linoleic acid and its subsequent peroxidation by means of the radicals generated by cells after stress exposure should have prevented major damage to cellular DNA. In fact, significant loss of viability in cells exposed to the various stress combinations was not observed. In the strain of Lactobacillus helveticus studied, epoxide formation was particularly enhanced by combinations of low $\mathrm{pH}$, oxidative and heat stresses. The presence of epoxides in cellular lipids (free or associated to phospholipids) can also be regarded as a step toward the release of oxidized or altered membrane fatty acids that could be further transformed and progressively released. Therefore, the remarkable enrichment of cell phospholipids with target molecules such as linoleic acid can be regarded as a mechanism associated with acclimation to heat stress and to conditions able to generate oxidative stress. In fact, the linoleic acid proportion in the cellular lipids of Lactobacillus helveticus increased at superoptimal temperatures. Likewise, it was observed that linoleic acid biosynthesis in E. coli provides survival advantages in the stationary phase (Rabinowitch et al., 1993; Di Russo et al., 1999). A new role for UFAs has been proposed by Chatterjee et al. (2000) who correlated an increase in the presence of UFAs in yeast cells with a decrease in the responsiveness of the stress response promoter element (STRE)-driven gene to heat and salt stresses. In fact, yeast cells supplemented with linoleic acid required a further $6^{\circ} \mathrm{C}$ temperature increase or $200 \mathrm{mM}$ higher salt concentration to maximally induce stress-response elements, demonstrating that unsaturation level influences the expression of STRE-driven genes (Chatterjee et al., 2000). Moreover, in bacterial cells the interaction between stress response proteins and lipid membrane unsaturation was described by Torok et al. (1997), who demonstrated the influence of composition and the physical state of the phospholipid bilayer on the binding of chaperonins (GroES-GroEL oligomers) to the cellular membrane.

The results achieved in this work represent further support for the hypothesis of Chatterjee et al. (2000) that plasma membranes and their level of unsaturation are involved in the transduction of heat stress into a biological signal, thus affecting the general stress response mechanisms of microbial cells.

\section{REFERENCES}

Aguilar, P. S., Cronan, J. E. \& de Mendoza, D. (1998). A Bacillus subtilis gene induced by cold shock encodes a membrane phospholipid desaturase. J Bacteriol 180, 2194-2200.

Brown, J. L., Ross, T., McMeekin, T. A. \& Nichols, P. D. (1997). Acid habituation of Escherichia coli and the potential role of cyclopropane fatty acids in low $\mathrm{pH}$ tolerance. Int $J$ Food Microbiol 37, 163-173.

Chatterjee, M. T., Seunath, A., Khalawan, S. A. \& Curran, B. P. G. (2000). Cellular lipid composition influences stress activation of the yeast general stress response elements (STRE). Microbiology 146, 877-884.

Cocconcelli, P. S., Parisi, M. G., Senini, L. \& Bottazzi, V. (1997). Use of RAPD and 16S rDNA sequencing for the study of Lactobacillus population dynamics in natural whey culture. Lett Appl Microbiol 25, 8-12.

Cronan, J. E. \& Gelmann, E. P. (1975). Physical properties of membrane lipids: biological relevance and regulation. Bacteriol Rev 39, 232-256.

Decallone, J., Delmee, M., Wauthoz, P., El lioul, M. \& Lambert, R. (1991). A rapid procedure for the identification of lactic acid bacteria based on the gas chromatographic analysis of cellular fatty acids. J Food Prot 54, 217-224. 
Di Russo, C. C., Black, P. N. \& Weimar, J. D. (1999). Molecular in road into the regulation and metabolism of fatty acids, lessons from bacteria. Prog Lipid Res 38, 129-197.

Dionisi, F., Golay, P. A., Elli, M. \& Fay, L. B. (1999). Stability of cyclopropane and conjugated linoleic acids during fatty acid quantification in lactic acid bacteria. Lipids 34, 1107-1115.

Dodd, C. R. E., Sharman, R. L., Bloomfield, S. F., Booth, I. R. \& Stewart, G. S. A. B. (1997). Inimical processes: bacterial selfdestruction and sub-lethal injury. Trends Food Sci Technol 8, 238-244.

Dykes, G. A., Cloete, T. E. \& von Holy, A. (1995). Taxonomy of lactic acid bacteria associated with vacuum-packaged meat spoilage by multivariate analysis of cellular fatty acids. Int J Food Microbiol 28, 89-100.

Evans, R. I., McClure, P. J., Gould, G. W. \& Russell, N. J. (1998). The effect of temperature on phospholipid and fatty acyl composition of non-proteolytic Clostridium botulinum. Int J Food Microbiol 40, 159-167.

Francis, G. L., Regester, G. O., Webb, H. A. \& Ballard, F. J. (1995). Extraction from cheese whey by cation-exchange chromatography of factors that stimulate the growth of mammalian cells. J Dairy Sci 78, 1209-1218.

Fulko, A. J. (1983). Fatty acid metabolism in bacteria. Prog Lipid Res 22, 133-160.

Guerzoni, M. E., Ferruzzi, M., Sinigaglia, M. \& Criscuoli, G. C. (1997). Increased cellular fatty acid desaturation as a possible key factor in thermotolerance in Saccharomyces cerevisiae. Can J Microbiol 43, 569-576.

Guillot, A., Obis, D. \& Mistou, M. Y. (2000). Fatty acid composition and activation of glycine-betaine transport in Lactococcus lactis subjected to osmotic stress. Int J Food Microbiol 55, 47-51.

Herold, M. \& Spiteller, G. (1996). Enzymatic production of hydroperoxides of unsaturated fatty acids by injury of mammalian cells. Chem Phys Lipids 79, 113-121.

Howlett, N. G. \& Avery, S. V. (1997). Induction of lipid peroxidation during heavy metal stress in Saccharomyces cerevisiae and influence of plasma membrane fatty acid unsaturation. Appl Environ Microbiol 63, 2971-2979.

Johnsson, T., Nikkila, P., Toivonen, L., Rosenqvist, H. \& Laakso, S. (1995). Cellular fatty acid profiles of Lactobacillus and Lactococcus strains in relation to oleic acid content of the cultivation medium. Appl Environ Microbiol 61, 4497-4499.

Keweloh, H. \& Heipieper, H. J. (1996). Trans unsaturated fatty acids in bacteria. Lipids 31, 129-136.

Leak, D. J., Ajken, P. J. \& Seyed-Mahmoudian, M. (1992). The microbial production of epoxides. Trends Biotechnol 10, 256-261.

Lonvaud-Funel, A. \& Desens, C. (1990). Constitution en acides gras des membranes des bactéries lactiques du vin. Sci Aliments 10, 3362-3364.

Moradas-Ferreira, P., Costa, V., Piper, P. \& Mager, W. (1996). The molecular defences against reactive oxygen species in yeast. $\mathrm{Mol}$ Microbiol 19, 651-658.

Morrison, W. R. \& Smith, L. M. (1964). Proportion of fatty acids methyl esters and methyl acetals from lipids with boron fluoridemethanol. J Lipid Res 5, 600-608.

Okuley, J., Lightner, J., Feldmann, K., Yadav, N., Lark, E. \& Browse, J. (1994). Arabidopsis FAD2 gene encodes the enzyme that is essential for polyunsaturated lipid synthesis. Plant Cell 6, 147-158.
Perry, C. K. (1964). Perry's Chemical Engineers' Handbook, 4th edn. New York: McGraw-Hill.

Piper, P. W. (1995). The heat shock and ethanol stress responses of yeast exhibited extensive similarity and functional overlap. FEMS Microbiol Lett 134, 121-127.

Rabinowitch, H. D., Sklan, D., Chace, D. H., Stevens, R. D. \& Fridovich, I. (1993). Escherichia coli produces linoleic acid during late stationary phase. J Bacteriol 175, 5324-5328.

Ratledge, C. \& Wilkinson, S. G. (editors) (1989). Microbial Lipids, vol. 2. London: Academic Press.

Rattray, J. B. M. (1988). Yeast. In Microbial Lipids, vol. 1, pp. 557-697. Edited by C. Ratledge \& S. G. Wilkinson. London: Academic Press.

Rees, C. E. D., Dodd, C. E. R., Gibson, P. T., Booth, I. R. \& Stewart, G. S. A. B. (1995). The significance of bacteria in stationary phase to food microbiology. Int J Food Microbiol 28, 263-275.

Russell, N. J. \& Fukanaga, M. (1990). A comparison of thermal adaptation of membrane lipids in psychrophilic and thermophilic bacteria. FEMS Microbiol Rev 75, 171-182.

Russell, N. J., Evans, R. I., TerSeeg, P. F., Hellemons, J., Verheul, A. \& Abee, T. (1995). Membrane as a target for stress adaptation. Int J Food Microbiol 28, 255-261.

Schnell, N., Krems, B. \& Entian, K. D. (1992). The PARI (YAP1/SN Q3) gene of Saccharomyces cerevisiae, a c-jun homologue, is involved in oxygen metabolism. Curr Genet 21, 269-273.

Smeds, A., Varmanen, P. \& Palva, A. (1998). Molecular characterization of a stress-inducible gene from Lactobacillus helveticus. J Bacteriol 18, 6148-6153.

Spiteller, G. (1996). Enzymic lipid peroxidation - a consequence of cell injury? Free Radic Biol Med 21, 1003-1009.

Steels, E. S., Learmonth, R. P. \& Watson, K. (1994). Stress tolerance and membrane lipid unsaturation in Saccharomyces cerevisiae grown aerobically and anaerobically. Microbiology 140, 569-576.

Suutari, M. \& Laakso, S. (1992). Temperature adaptation in Lactobacillus fermentum: interconversion of oleic, vaccenic and dihydrosterculic acid. J Gen Microbiol 138, 445-450.

Suutari, M. \& Laakso, S. (1994). Microbial fatty acid and thermal adaptation. Crit Rev Microbiol 20, 285-328.

Suutari, M., Linkkonen, K. \& Laakso, S. (1990). Temperature adaptation in yeast: the role of fatty acids. J Gen Microbiol 136, 1469-1474.

Swaving, J. \& de Bont, J. A. M. (1998). Microbial transformation of epoxides. Enzyme Microb Technol 22, 19-26.

Torok, Z., Horvath, I., Goloubinoff, P., Kovacs, E., Glatz, A., Balogh, G. \& Vigh, L. (1997). Evidence for a lipochaperonin: association of active protein-folding GroESL oligomers with lipids can stabilize membranes under heat shock conditions. Proc Natl Acad Sci US A 94, 2192-2197.

Van de Vossenberg, J. L. C. M., Driessen, A. J. M., da Costa, M. S. \& Konings, W. N. (1999). Homeostasis of the membrane proton permeability in Bacillus subtilis grown at different temperatures. Biochim Biophys Acta 1419, 97-104.

Wijeyaratne, S. C., Ohta, K., Chavanichi, S., Mahamontri, V., Nilubol, N. \& Hayashida, S. (1986). Lipid composition of a thermotolerant yeast Hansenula polymorpha. Agric Biol Chem 50, 827-832.

Received 4 August 2000; revised 2 February 2001; accepted 4 April 2001. 